\title{
Manajemen User Interface Pada Game 2D Berbasis Finite State Machine
}

\author{
Fajar Hariadi
}

Fakultas Sains dan Teknologi, Prodi Teknik Informatika, Universitas Kristen Wira Wacana Sumba, Kota Waingapu, Indonesia

Email: fajar@unkriswina.ac.id

\begin{abstract}
Abstrak
User interface merupakan tampilan yang pertama kali dilihat dan digunakan oleh user untuk berinteraksi dalam game. Banyaknya menu dan fungsi yang berbeda di setiap bagian user interface memberikan tantangan tersendiri melakukan manajemen. Pada tulisan ini kita akan melihat proses manajemen user interface dan fungsi-fungsi pada sub-menu menggunakan Finite State Machine (FSM) pada game 2 dimensi.
\end{abstract}

Kata Kunci: FSM, Finite State Machine, User Interface, Game 2 Dimensi, Manajemen Menu

Abstract

User interface is very important in a game cause it manages how the player interacts with the game itself. Managing a lot of menu in the user interface is quite challenging for the developer of the game. The menu can have a lot of different function in each part of the sub-menu. So in this article, we will see how to use the Finite State Machine concept for solving the management problems

Keywords: FSM, Finite State Machine, User Interface, 2D Game, Menu Management

\section{PENDAHULUAN}

User Interface atau antarmuka pemakai merupakan salah satu mekanisme komunikasi antara pengguna (user) dengan sistem. Melalui user interface ini user dapat berkomunikasi dengan sistem yang digunakan. Sistem pun dapat menampilkan informasi dan atau feedback yang sesuai dengan yang diinginkan oleh user. Di dalam game user interface digunakan agar objek-objek dalam game dapat merespon sesuai dengan keinginan pemainnya. Namun adakalanya user interface dalam game tidak termanajemen dengan baik akibat banyaknya menu dan fungsi yang berada dalam user interface. Oleh karena itu tujuan dari penelitian ini adalah membentuk logika yang digunakan dalam user interface dalam memanajemen setiap fungsi dalam user interface, dan salah satu metode yang bagus menangani permasalahan seperti ini adalah Finite State Machine (FSM) yang bekerja berdasarkan kejadian-kejadian atau even yang terjadi di dalam sistem.

\section{TEORITIS}

\subsection{Game}

Game adalah suatu sistem formal tertutup yang melibatkan pemain dalam sebuah konflik yang berbeda-beda yang dedifinisikan sebagai salah satu tipe aktivitas, dimana terdapat pemain yang berusaha memenuhi tujuan sesuai dengan aturan yang dirancang[1]. Oleh karena itu setiap game memerlukan partisipan untuk membuat berbagai macam strategi dalam jangka pendek dan jangka panjang untuk mencapai tujuan dari game[2].

Pada awalnya game dibuat dan dibagi menjadi 3 jenis yang sering disebut dengan genre yaitu genre arcade yang merupakan game berdasarkan koordinasi mata dan tangan, genre strategi atau menajemen yang focus kepada kemampuan berpikir dan mengelola pola permainan, dan yang terakhir adalah genre petualangan yang mengutamakan naratif atau pemaparan cerita dalam game[3]. Seiring perkembangan genre game semakin berkembang dengan munculnya genre baru dan perpaduan antar genre yang disebut dengan sub-genre. Menurut Lars Konzack genre game telah berkembang menjadi Strategy game, Simulator, Action, Edukasi, Casual, Adventure \& Role Playing Game[4].

\subsection{User Interface}

Antarmuka pengguna atau User Interface memberikan form berbentuk fisik terhadap informasi digital dengan tujuan menjembatani jarak antara dunia digital dan dunia nyata[5]. User interface merupakan visualisasi yang ditampilkan pada layar dimana di dalamnya terdapat kurosr yang dapat digeser dan menu yang dapat dipilih[6]. Menurut Anneta [7] pada penelitian tentang serious game ada enam elemen utama dalam membentuk game yaitu:

a. Identity, kemampuan untuk mempengaruhi pola pikir pemain seolah-olah berada dalam game.

b. Immersion, mendorong pemain untuk mencapai tingkat keberhasilan yang makin tinggi dalam bermain game.

c. Interactivity, menggambarkan setiap komponen saling terhubung dan ada reaksi timbal balik diantaranya.

d. Increasing Complexity, kondisi dimana game memiliki beberapa level dengan tingkat kesulitan yang berbeda

e. Informed Teaching, game memberikan feedback tingkat kemampuan user dan atau menambahkan capaian seperti pemberian skor atau reward ketika pemain mencapai suatu tujuan dalam game. 
f. Instuctional, kondisi dimana game dapat dipergunakan sebagai media pemberi atau penyeampaian instruksi. Pada bagian interactivity inilah user interface sangat berperan dalam memberi pengalaman timbal balik yang menyenangkan antara user dan game.

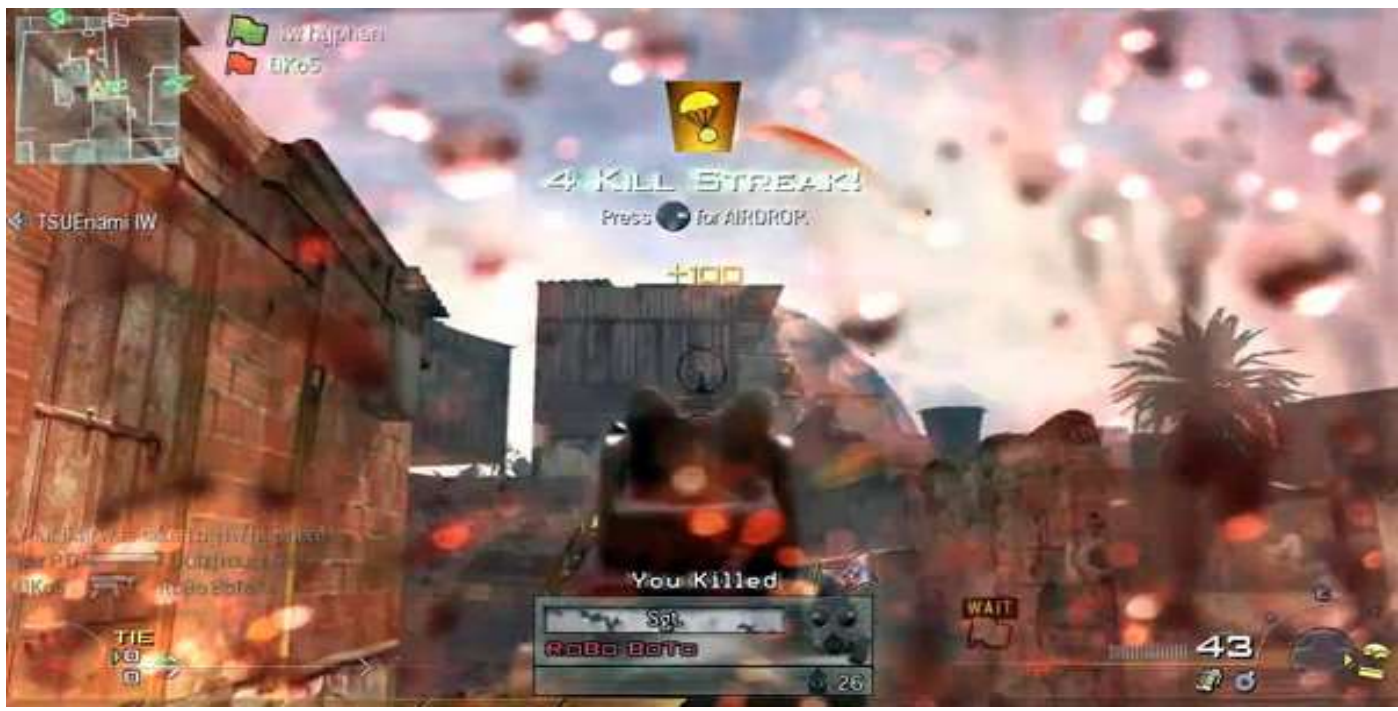

Gambar 1. Contoh HUD (Heads-Up Display)

User interface yang paling sering ditampilkan adalah user interface berupa HUD (Heads-Up Display). HUD merupakan tampilan User Interface transparan yang merepresentasikan data tanpa mengharuskan user mengalihkan pandangannya. HUD seringkali digunakan untuk menampilkan beberapa informasi sekaligus seperti item, progress pemain dalam game, atau tujuan yang telah dicapai dalam game[8].

\subsection{Finite State Machine (FSM)}

Finite State Machine (FSM) merupakan metodologi perancangan system untuk memodelkan perilaku (behaviour) dari system atau objek yang kompleks dengan kondisi yang telah didefinisikan. FSM masuk dalam ranah pengambilan keputusan (Decision Making)[9]. Oleh karena itu FSM merupakan bagian dari ilmu yang mempelajari kecerdasan buatan (Artificial Inteligence).

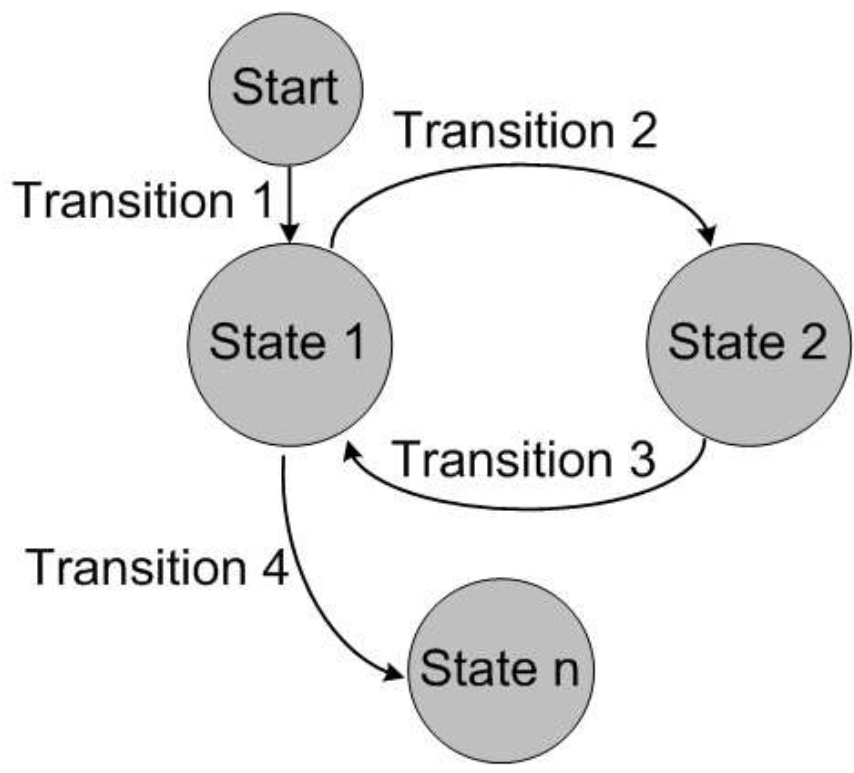

Gambar 2. Contoh Finite State Machine

Dalam FSM terdapat state-state yang memiliki tindakan atau perilaku yang dapat berpindah dari satu state ke state lainnya berdasarkan input atau event tertentu. Di dalam setiap state terdapat fungsi-fungsi yang akan dijalankan jika state tersebut aktif. Objek dalam game akan memulai dengan state awal (Initial State) kemudian akan menunggu adanya input atau event yang memicu transisi ke state lainnya, setiap objek game hanya dapat menjalankan satu state pada satu waktu[10]. 


\section{METODE PENELITIAN}

\subsection{Alur Kerja}

Penelitian ini dibuat mengikuti alur kerja dengan metode waterfall. Metode waterfall yang digunakan terlihat pada gambar 3.1 di bawah ini:

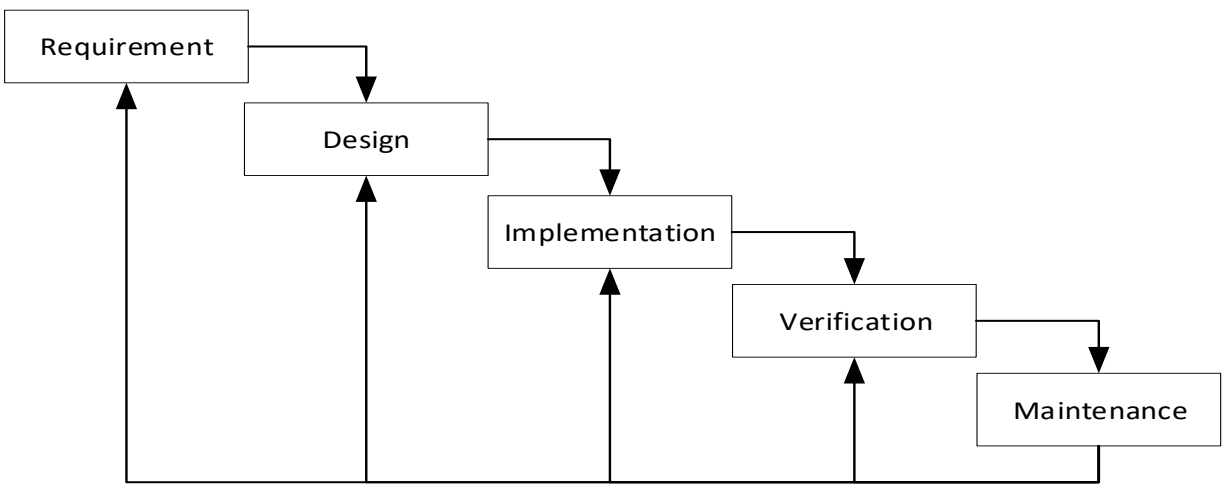

Gambar 3 Metode Waterfall

a. Requirement

Pada tahapan ini peneliti akan menganalisa kebutuhan-kebutuhan yang akan dipergunakan dalam penelitian ini. Dimulai dari mencari bahan referensi, kebutuhan perangkat lunak, dan hal-hal lain yang mesti dipersiapkan.

b. Design

Proses desain dilakukan dengan mengambil hasil analisa kebutuhan dan mendesain alur kerja, arsitektur aplikasi yang mesti dibangun, algoritma dan metode yang digunakan.

c. Implementation

Proses implementasi dimulai dengan membuat menerapkan desain user interface dan metode FSM dan algoritma-algoritma pendukung lainnya yang sudah dibuat ke dalam aplikasi menggunakan unity 3D dan bahasa pemograman.

d. Verification

Verifikasi akan dilakukan ketika proses implementasi selesai dilaksanakan untuk memastikan aplikasi yang dibangun telah berjalan dengan baik.

e. Maintenance

Setelah melewati proses verifikasi aplikasi yang dibangun akan dilakukan perawatan guna memperbaiki proses implementasi yang kurang baik, bug, perbaikan kinerja aplikasi, atau pembaharuan dari sistem aplikasi.

\subsection{Desain Sistem}

Rancangan yang dibuat terdiri dari dua bagian utama yaitu desain user interface yang dibuat dan desain proses kerja metode FSM dalam memanagement user interface yang dibuat.

\subsubsection{User Interface}

User interface (UI) untuk yang dirancang terdiri dari tiga bagian besar user interface yaitu UI Utama (Main Menu), UI ketika game berjalan, dan UI untuk melakukan konfigurasi pengaturan dalam game.

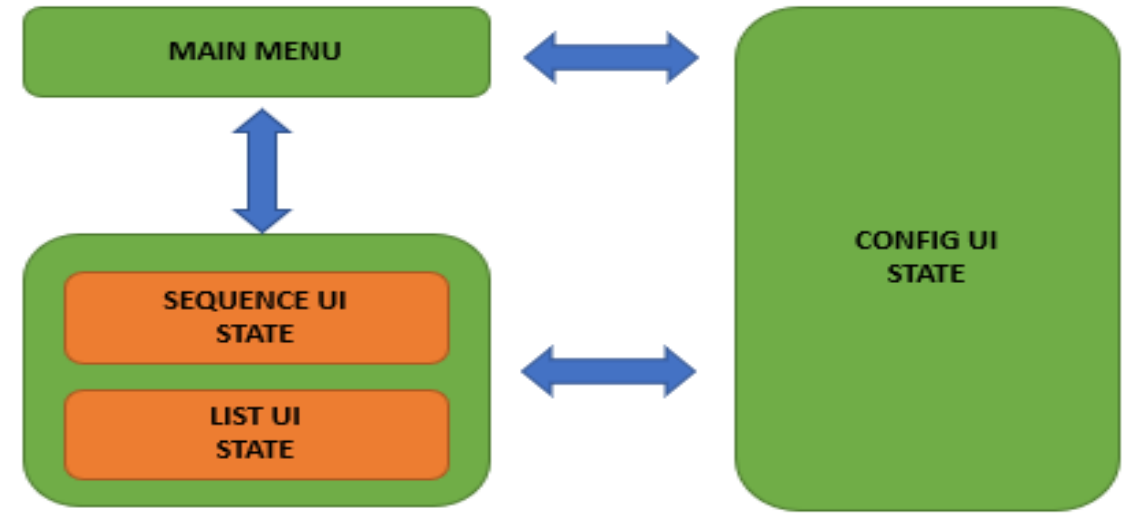

Gambar 4. Rancangan User Interface 
Pada In Game UI terdapat tiga Sub-UI, user tidak dapat berpindah langsung antar sub-UI tersebut. Untuk dapat berpindah user harus kembali terlebih dahulu menuju Main Menu baru kemudian memilih bentuk In Game UI yang diinginkan.

\subsubsection{FSM User Interface Manager}

Pada bagian Finite State Machine (FSM) yang digunakan tiap state akan menampilkan UI yang sesuai dengan state tersebut dan tiap transisi dipicu oleh event yang terjadi saat tombol (button) ditekan.

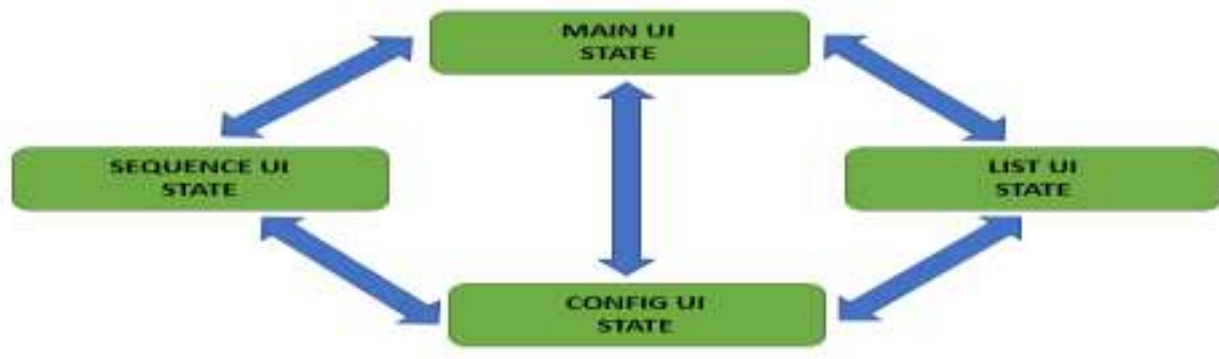

Gambar 5 Finite State Machine (FSM) User Interface

MainUI merupakan state yang pertama kali dilaksanakan ketika game berjalan. Sedangkan Exit state merupakan state yang dilaksanakan ketika game dihentikan. Sedangkan ketiga state lainnya akan dilaksanakan sesuai dengan pemicu yang terjadi dalam kasus ini pemicu adalah tombol dalam game. Jika tidak ada pemicu atau event yang terjadi maka state tersebut akan bertahan sambal menunggu terjadinya event pemicu untuk berpindah state.

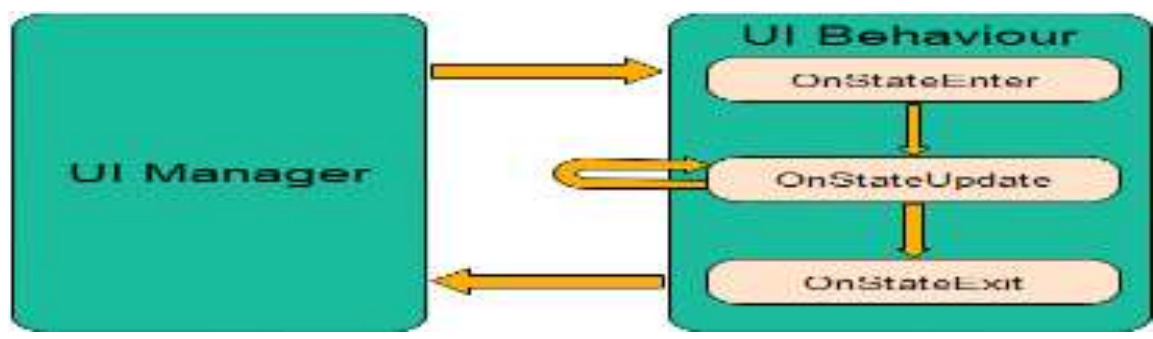

Gambar 6 Behaviour dalam State

UI manager bertugas untuk menentukan transisi antar state, yang terjadi ketika pada saat state aktif terjadi event yang memicu untuk merubah kondisi state untuk berpindah ke state lainnya. Setiap state dalam FSM untuk memanajemen User Interface memiliki tiga perilaku (Behaviour) utama yaitu:

a. OnStateEnter(), fungsi ini akan dijalankan pada saat proses awal ketika state dijalankan, dalam kasus ini digunakan untuk mengaktifkan User Interface pada state tersebut.

b. OnStateUpdate(), fungsi ini dijalankan tiap frame yang terjadi ketika state aktif. Digunakan untuk merespon elemen-elemen lainnya ketika user interface yang aktif.

c. OnStateExit() yang dijalankan ketika state bertransisi ke state lainnya, digunakan untuk menonaktifkan User Interface tersebut.

Fungsi-fungsi lain pada menu yang sedang aktif diletakkan pada bagian behaviour OnStateUpdate.

\section{ANALISA DAN PEMBAHASAN}

Penerapan FSM UI Manager yang mengatur menu yang berhak tampil di layer menggunakan animator sehingga dapat dilihat state atau menu mana yang sedang aktif dan yang tidak aktif.

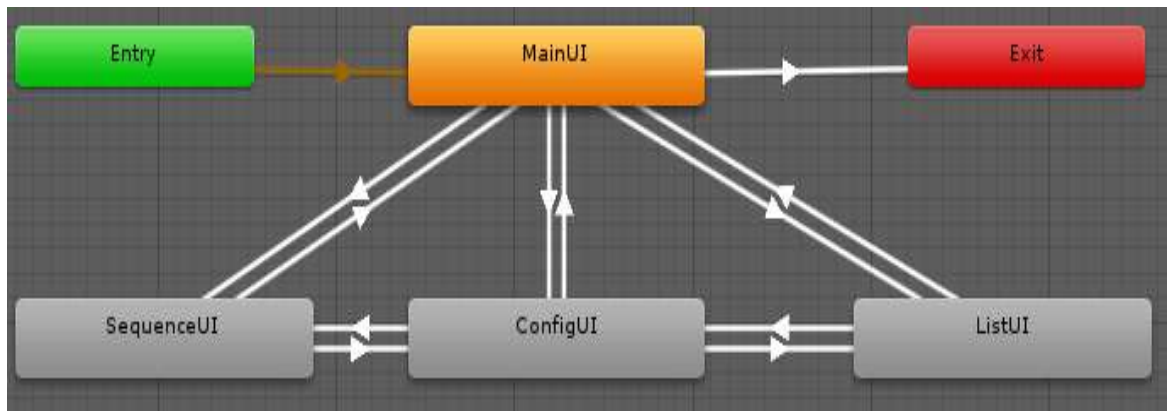

Gambar 7. FSM UI Manager

Fajar Hariadi | http://ejurnal.stmik-budidarma.ac.id/index.php/mib | Page 147 
State FSM yang pertama kali aktif adalah state entry. Setelah itu secara otomatis akan berpindah kepada state MainUI. Perpindahan dilakukan secara otomatis tanpa trigger atau pemicu apapun. State MainUI akan mengaktifkan menu utama, sehingga menu utama akan muncul pada layer.

Dari menu utama pemain dapat berpindah state untuk mengaktifkan menu lainnya. Perpindahan ini menggunakan pemicu berupa tombol pada menu yang sedang aktif. State Exit digunakan untuk menghandle fungsi-fungsi yang diperlukan ketika pemain keluar dari permainan.

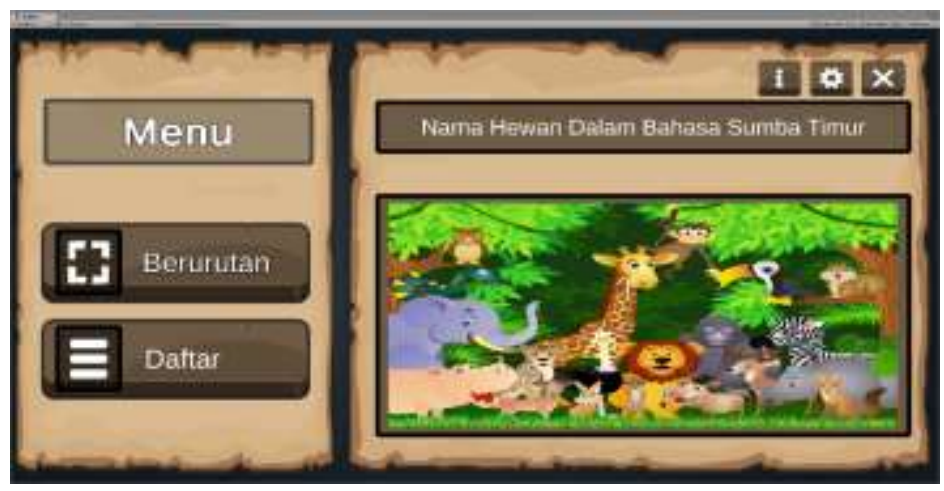

Gambar 8. Menu Utama

Menu Utama memiliki 5 buah tombol yang dapat digunakan untuk mengakses fungsi yang berbeda. Tombol berurutan, daftar, dan pengaturan digunakan untuk beralih ke menu lainnya. Sedangkan tombol informasi digunakan untuk menampilkan informasi, dan tombol exit untuk keluar permainan.

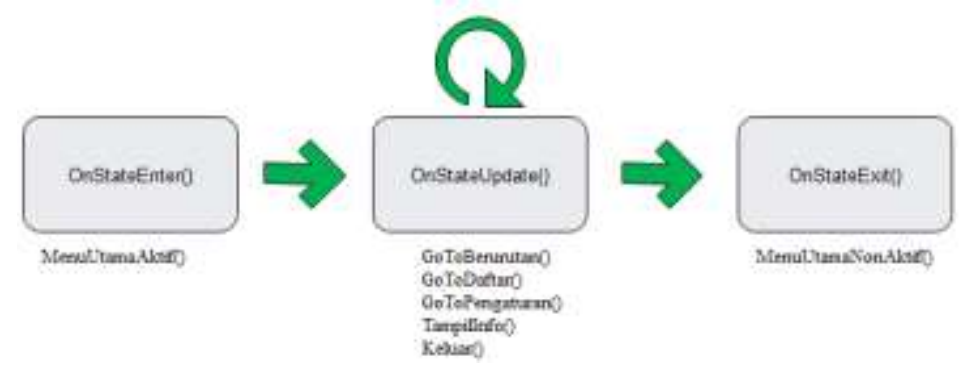

Gambar 9. Behaviour Menu Utama

Ketika state MainUI aktif akan memasuki tiga state utamnaya. Pada state enter, ketika pertama kali state ini mulai aktif, maka fungsi untuk mengaktifkan menu utama akan dipicu sehingga menu utama akan ditampilkan. Selama menu utama aktif maka state akan selalu melakukan state update untuk mengecek apakah ada interaksi baru dari user terhadap menu yang tampil.

Pada state update terdapat beberapa fungsi yang dapat dipicu jika menekan salah satu tombol pada menu. Tombol berurutan akan mengaktifkan fungsi GoToBerurutan() yang mana akan menaktifkan state SequenceUI kemudian state MainUI akan memasuki OnStateExit() dimana state MainUi akan diakhiri. Demikian pula kerja fungsi-fungsi lainnya bekerja dengan cara yang sama.

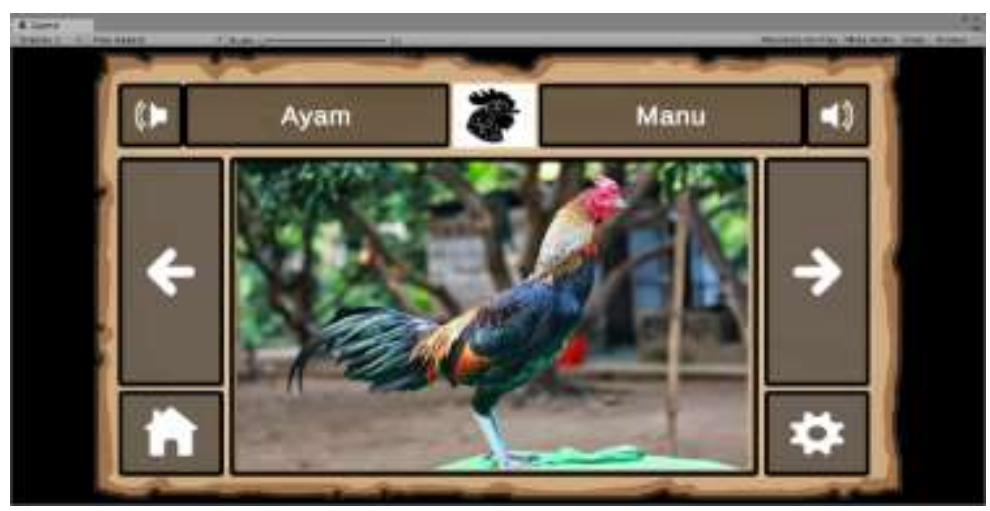

Gambar 10. Menu Berurutan

Pada menu ini terdapat 6 buah tombol. Satu buah tombol untuk kembali ke menu utama. Satu buah tombol untuk menampilkan pengaturan. Dua buah tombol untuk navigasi. Dua buah tombol untuk mengaktifkan audio nama hewan. Keenam tombol ini memiliki fungsi yang dapat diaktifkan ketika state berada kondisi OnStateUpdate(). 
Tabel 1. Fungsi-fungsi pada State MainUI

\begin{tabular}{ll}
\hline Nama Fungsi & Efek \\
\hline MenuUtamaAktif() & Menampilkan Menu Utama \\
MenuUtamaNonAktif() & Menyembunyikan Menu Utama \\
GoToBerurutan() & Mengaktifkan State SequenceUI \\
GoToDaftar() & Mengaktifkan State ListUI \\
GoToPengaturan() & Mengaktifkan State ConfigUI \\
TampilInfo() & Menampilkan Pesan Informasi \\
Keluar() & Keluar Permainan \\
\hline
\end{tabular}

Selain mengaktifkan beberapa fungsi pada table 1 di atas. Tombol-tombol pada menu utama juga menjadi trigger untuk perpindahan state dari state MainUI ke state lainnya. Kecuali tombol informasi yang hanya menampilkan papan informasi tanpa merubah state.

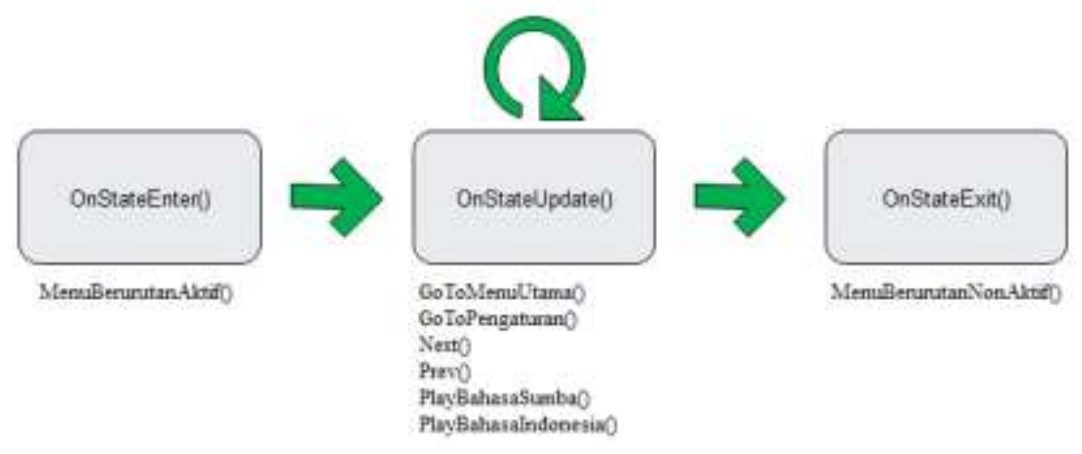

Gambar 11. Behaviour Menu Berurutan

Memasuki state ini akan mengaktifkan menu berurutan melalui fungsi MenuBerurutanAktif(). Fungsifungsi lain yang terdapat pada state ini, terlihat pada table 2 di bawah ini.

Tabel 2. Fungsi-Fungsi pada State ListUI

\begin{tabular}{ll}
\hline Nama Fungsi & Efek \\
\hline MenuBerurutanAktif() & Tampilkan Menu Berurutan \\
MenuBerurutanNonAktif() & Sembunyikan menu berurutan \\
GoToPengaturan() & Mengaktifkan State ConfigUI \\
GoToMenuUtama() & Mengaktifkan State MainUI \\
PlayBahasaSumba() & Memainkan Suara Nama Hewan \\
PlayBahasaIndonesia() & Memainkan Suara Nama Hewan \\
\hline
\end{tabular}

Selain memiliki fungsinya masing-masing tombol juga menjadi trigger transisi state. Trigger yang digunakan untuk merubah state pada menu ini adalah tombol Home dan tombol pengaturan. Sedangkan tombol lainnya hanya menjalankan fungsinya tanpa merubah state.

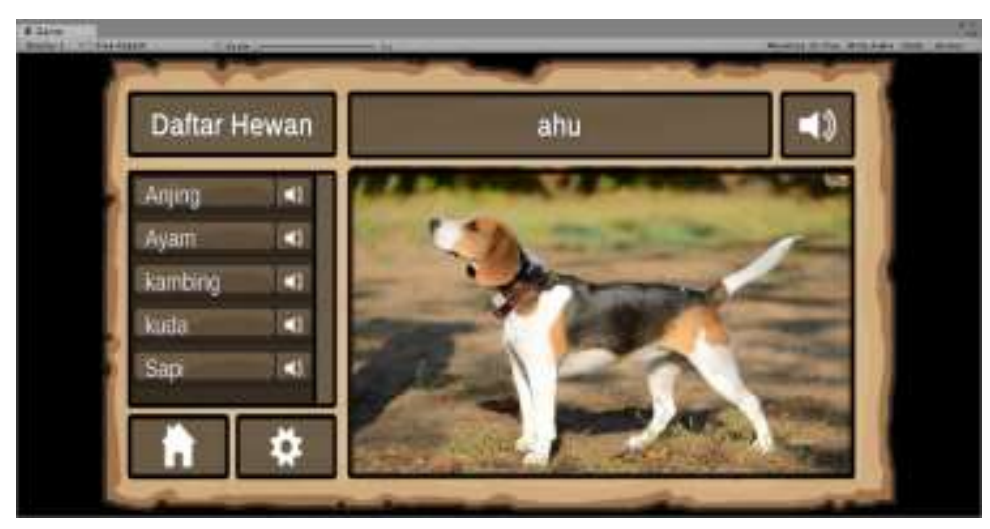

Gambar 12. Menu List

Tampilan pada menu ini memiliki lebih banyak tombol. Tombol-tombol ini di-generate secara otomatis dengan jumlah dua kali jumlah hewan. Tombol pertama untuk memilih hewan dan tombol kedua digunakan untuk memainkan suara nama hewan sesuai dengan nama hewan yang dipilih. 


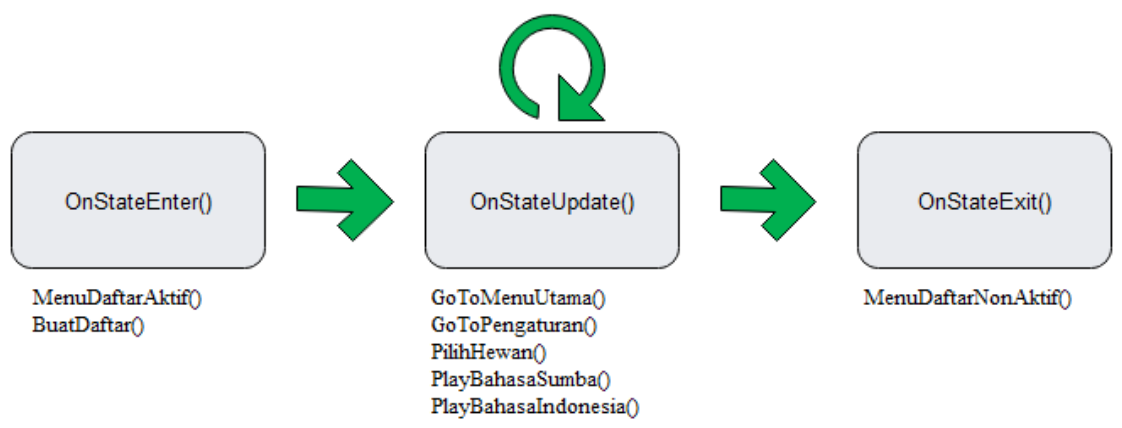

Gambar 13. Behaviour Menu List

Pada state ListUI ini, bagian OnStateEnter memiliki dua fungsi. Fungsi pertama digunakan untuk menampilkan menu daftar hewan. Fungsi kedua digunakan untuk membuat daftar tombol yang berisi nama dan tombol yang digunakan untuk memainkan suara nama hewan.

Tabel 3. Fungsi-Fungsi pada State DaftarUI

\begin{tabular}{ll}
\hline Nama Fungsi & Efek \\
\hline MenuDaftarAktif() & Tampilkan Menu Daftar \\
BuatDaftar() & Membuat Daftar Hewan \\
MenuDaftarNonAktif() & Sembunyikan menu Daftar \\
GoToPengaturan() & Mengaktifkan State ConfigUI \\
GoToMenuUtama() & Mengaktifkan State MainUI \\
PlayBahasaSumba() & Memainkan Suara Nama Hewan \\
PlayBahasaIndonesia() & Memainkan Suara Nama Hewan \\
\hline
\end{tabular}

Tombol yang digunakan sebagai trigger transisi state pada menu ini hanya tombol home dan tombol pengaturan. Tombol lainnya hanya menjalankan fungsi yang sesuai dengan tombol itu sendiri saja.

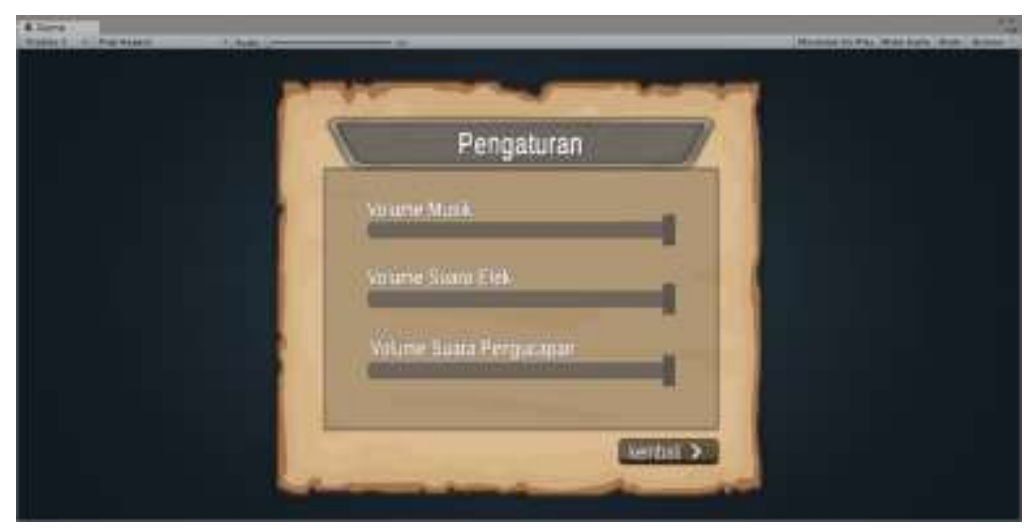

Gambar 14. Menu Pengaturan

Menu pengaturan memiliki tiga buah slider yang masing-masing mengatur besarnya volume suara music, efek, dan audio pengucapan nama hewan. Serta satu buah tombol untuk kembali ke menu yang sebelumnya aktif.

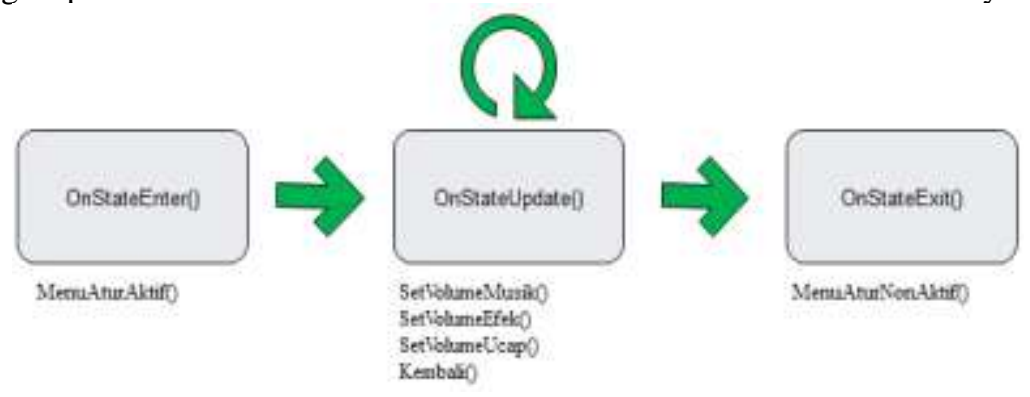

Gambar 15. Behaviour Menu Pengaturan

Pada state ini hanya satu buah tombol yang dapat digunakan untuk berpindah state menuju state yang sebelumnya aktif, baik itu menu utama, daftar atau menu berurutan. Sedangkan slider yang digunakan hanya mengaktifkan fungsi pengaturan volume mixer untuk mengatur suara music, efek, dan pengucapan nama hewan tanpa memicu perpindahan state. 
Tabel 4. Fungsi-Fungsi pada State ListUI

\begin{tabular}{ll}
\hline Nama Fungsi & Efek \\
\hline MenuAturAktif() & Tampilkan Menu Pengaturan \\
MenuAturNonAktif() & Sembunyikan Menu Pengaturan \\
SetVolumeMusik() & Mengatur Suara Musik \\
SetVolumeEfek() & Mengatur Suara Efek \\
SetVolumeUcap() & Mengatur Suara Pengucapan \\
\hline
\end{tabular}

Hanya satu buah tombol yang memiliki kemampuan sebagai trigger untuk transisi state, yaitu tombol kembali. fungsi-fungsi lain pada state ini digunakan untuk mengatur volume mixer.

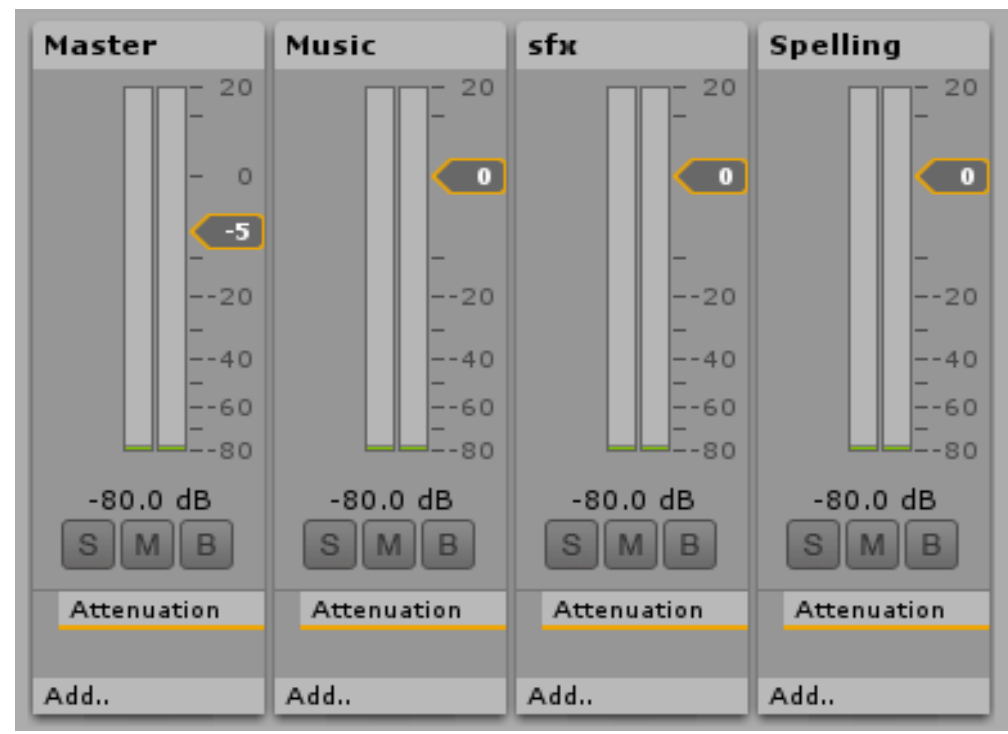

Gambar 16. Behaviour Menu Berurutan

Volume mixer ini memiliki 4 buah kanal. Kanal master digunakan untuk mengatur besar kecilnya suara. Kanal musik mengatur besar kecilnya suara music. Sedangkan suara efek dan pengucapan diatur oleh kanal sfx dan kanal spelling. Semua kanal ini diatur pada menu pengaturan melalui fungsi SetVolumeMusik, SetVolumeEfek, dan SetVolumeUcap.

State terakhir yang dapat diaktifkan adalah state exit. Dimana state ini akan menutup permainan dan mengakhiri rangkaian state yang ada pada Finite State Machine yang digunakan sebagai manajemen user interface pada permainan ini.

Seluruh fungsi-fungsi yang ada pada pemainan ini dapat juga digunakan langsung tanpa FSM atau menggunakan pemodelan lain sejenis FSM. Peran FSM disini adalah sebagai peng-organisir fungsi-fungsi tersebut dalam bentuk state-state yang dapat berpindah dari satu state ke state lainnya.

Setelah semua desain telah berhasil diimplementasikan, menu dan sub-menu di uji fungsinya satu per satu, dan kesemuanya dapat berjalan dengan baik di bawah manajemen metode Finite State Machine (FSM).

\section{KESIMPULAN}

Finite State Machine (FSM) merupakan model kecerdasan buatan yang dapat diimplementasikan di setiap bagian sistem yang dapat direpresentasikan sebagai state. Salah satunya adalah user interface. Pendekatan ini dapat menyederhanakan berbagai macam fungsi yang ada menjadi kelompok-kelompok dalam state tanpa merubah pola atau pernyataan dalam setiap fungsi yang ada.

Proses penyederhanaan dilakukan dengan mengelompokkan fungsi-fungsi yang sudah ada menjadi sebuah state, kemudia membuat ketentuan atau aturan dalam perpindahan dari satu state ke state lainnya.

Setelah di uji coba seluruh fungsi pada menu dan sub-menu di bawah manajemen Finite State machine (FSM) dapat berjalan dengan baik.

\section{REFERENCES}

[1] A. Chowanda and Y. L. Prasetio, "Perancangan Game Edukasi Bertemakan Sejarah Indonesia," Proc. Semant., pp. 151-155, 2012.

[2] M. Sørensen, "Learning with simulation games,” Eval. Hotel Simul. Games' Ef. High. Acad. Perform. within Serv. Hosp. Copenhagen Bus. Sch. Handel., 2010.

[3] G. Skirrow, "Hellivision: an analysis of video games," High theory/low Cult. Anal. Pop. Telev. Film, pp. 115-142, 1986.

[4] L. Konzack, "Video game genres," in Encyclopedia of Information Science and Technology, Third Edition, IGI Global, 2015, pp. 
JURNAL MEDIA INFORMATIKA BUDIDARMA, Vol 3, No 2, April 2019

ISSN 2614-5278 (media cetak)

ISSN 2548-8368 (media online)

Hal 144-152 | DOI: 10.30865/mib.v3i2.1159

3070-3076.

[5] W. K. Bong, W. Chen, and A. Bergland, "Tangible User Interface for Social Interactions for the Elderly: A Review of Literature.," Adv. Human-Computer Interact., pp. 1-15, May 2018.

[6] J. H. Lemelson and J. H. Hiett, "Selectively controllable heads-up display system." Google Patents, 25-Jan-2005.

[7] L. A. Annetta, "The 'I's' have it: A framework for serious educational game design.," Rev. Gen. Psychol., vol. 14, no. 2, p. 105,2010

[8] E. Fagerholt and M. Lorentzon, "Beyond the HUD-user interfaces for increased player immersion in FPS games," 2009.

[9] I. Millington and J. Funge, Artificial intelligence for games. CRC Press, 2009.

[10] A. Nareyek, "AI in computer games," Queue, vol. 1, no. 10, p. 58, 2004. 